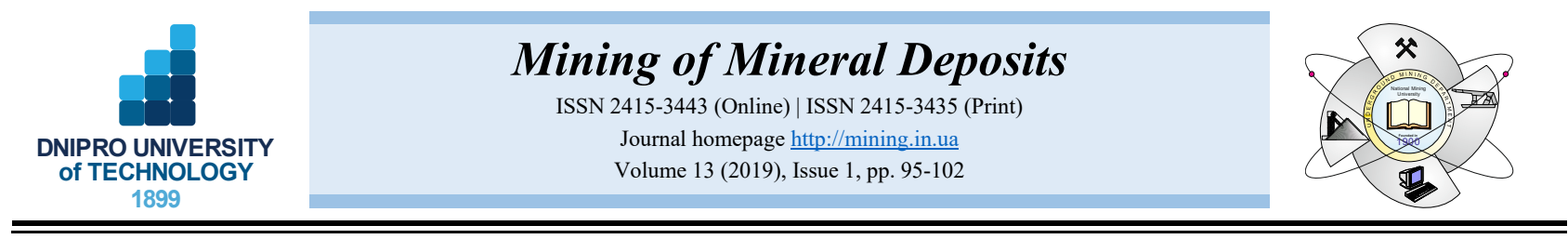

UDC 622.02:622.7.016

https://doi.org/10.33271/mining13.01.095

\title{
VARIATIONS OF PHYSICO-MECHANICAL, MINERALOGICAL AND GEOCHEMICAL PROPERTIES OF MARBLE UNDER THE INFLUENCE OF WEATHERING
}

\author{
N.O. Ogunsola ${ }^{1}$, A.I. Lawal ${ }^{1 *}$, M.A. Saliu ${ }^{1}$ \\ ${ }^{1}$ Federal University of Technology Akure, Akure, Nigeria \\ *Corresponding author: e-mail ailawal@futa.edu.ng,tel.+2348067568693
}

\begin{abstract}
Purpose. To investigate the physico-mechanical, mineralogical and geochemical properties variations of Igbeti marble, south-western Nigeria under the influence of weathering.

Methods. About twenty representative samples were collected at a varying depth up to a depth of 30 meters from the study area. The samples represented a group of unweathered, slightly weathered, moderately weathered and highly weathered rocks using weathering classification indices. Thin sections were prepared for textural and mineralogical studies of the rock samples. The chemical composition analyses of the rock samples were conducted using X-ray Fluorescence spectrometry (XRF). The physico-mechanical properties were also evaluated.

Findings. The results showed that noticeable mineralogical and chemical changes occur in the rock fabric because of the increase in weathering state. The laboratory tests result also revealed that weathering reduces the strength of the rock.

Originality. The transformation of physical and mechanical properties of rocks because of weathering is a major concern to the geotechnical engineers. These properties have been investigated by the researchers, but the majority of the available researches were conducted on weathered sedimentary and igneous rocks while that of metamorphic rock is very scarce. Hence, this study investigates the influence of weathering on physico-mechanical, mineralogical and geochemical properties of Igbeti marble, south-western Nigeria.
\end{abstract}

Practical implications. The obtained results show that the transition of selected rock properties as a result of weathering would significantly affect slope stability and performance of the rock in engineering applications.

Keywords: marble, weathering, physico-mechanical properties, mineralogical properties, thin section, XRF, geochemical studies

\section{INTRODUCTION}

Rock has been used as a construction material since historical times, with marble occupying a special place as it has been used as a facing stone for many famous structures, e.g. temples, mosques, churches, palaces, monuments, etc. because of its pleasing colours, attractive patterns, and designs. Marble is a metamorphic rock composed essentially of calcite $\left(\mathrm{CaCO}_{3}\right)$, dolomite [CaMg $\left.\left(\mathrm{CO}_{3}\right)_{2}\right]$, or a combination of the two, with a fineto coarse-grained crystalline texture (Serra, 2006). The surface of marble crumbles readily when exposed to a moist, acid atmosphere, but marble is durable in a dry atmosphere and when protected from rain. Investigating the effects of weathering on carbonate rock types appear very important nowadays due to the increasing popularity of the rocks in external architectural usage and engineering applications in all climatic zones. The carbonate rock was used in many historical buildings and sculptures in the past, and the signs of extensive weathering can be recognized on some of these carbonate-made structures. However, limited information is available on the physicochemical, mineralogical and physico-mechanical characteristics of carbonate rocks most especially marble rock.

Weathering in marble rock type has deep impacts on both physical and mechanical properties of the rocks as well as of the rock masses. The changes in mineral content and the increase of pore volume promote the action of mechanical disintegration and chemical decomposition (Thuro \& Scholz, 2004). Also, variations in weathering grades usually result in varying engineering properties of the rock. Understanding the effects of weathering on engineering properties of rocks is imperative because it may be the primary criterion for determining the depth of excavation, cut slope design, method and ease of excavation, and use of excavated materials (Irfan, 1996).

(C) 2019. N.O. Ogunsola, A.I. Lawal, M.A. Saliu. Published by the National Mining University on behalf of Mining of Mineral Deposits.

This is an Open Access article distributed under the terms of the Creative Commons Attribution License (http://creativecommons.org/licenses/by/4.0/),

which permits unrestricted reuse, distribution, and reproduction in any medium, provided the original work is properly cited. 
Thus, it is important to recognize the role played by the weathering process in the performance of rock in engineering applications (Rigopoulos, Tsikouras, Pomonis, \& Hatzipanagiotou, 2010). The investigation of the degree and pattern of weathering on the selected deposits will reduce the cost and make the work of on-site exploration and excavation easy. The purpose of this research is to investigate the effect of petrographic and geochemical characteristics on rock strength and especially the relationships between the engineering properties and specific petrographic transformations which take place during weathering process and are very common in marble. This is very necessary, to enhance the understanding of the effect of the internal mechanism of rock structure and its engineering properties.

In what follows, the details of the sample collection and preparation is presented. Then the quantitative grading of the weathering is described. The details of the laboratory procedures used in determining the rock properties are explained. Empirical equations are proposed for easy determination of the rock properties. This will greatly reduce the time and efforts required for a laboratory experiment.

\section{MATERIAL AND METHODS}

\subsection{Sample collection and preparation}

Igbeti is located within latitudes $8^{\circ} 40^{\prime} \mathrm{N}$ and $9^{\circ} 05^{\prime} \mathrm{N}$ and longitudes $3^{\circ} 45^{\prime} \mathrm{E}$ and $4^{\circ} 15^{\prime} \mathrm{E}$ in Olorunsogo Local Government Area of Oyo State, Nigeria. Igbeti is underlain by Pre-Cambrian rocks which forms part of the basement complex of south-western Nigeria. There are three lithological units of the crystalline basement complex, comprising; migmatite-gneiss complex (quartzite, gneissic rocks); Low to medium grade metasediments (green schists facies, namely quartz schist and mica schist); The Pan African Granitoids (older granites) which are linked to late-tectonic intrusions (Musbau, 2014). The samples used for this research work were collected from Igbeti.

Many marble block samples (20 in numbers) of different weathering grades were taken from operating pit from various locations at a varying depth up to a depth of $30 \mathrm{~m}$. Sample preparations for the physico-mechanical properties were conducted in the Rock mechanics laboratory at the Federal University of Technology Akure (FUTA). Preparation of these samples, test procedures and calculations followed the relevant ASTM (2000), ISRM (1985) standards. The preparation of samples for petrographic analysis was conducted at the petrology section of the geology laboratory, University of Ibadan, Oyo State while that of geochemical analysis was conducted at the Centre for Energy Research and Development, Obafemi Awolowo University Ile-Ife, Osun State, Nigeria.

\subsection{Weathering grade classification}

The marble specimens were grouped qualitatively into different weathering grades using three indexes viz.: colour, surface texture and friability (rock to soil ratio) in relation to the depth of occurrence, the weathering state was assigned. Weathering states 1 through 4 were assigned to all the marble specimens; $W_{1}$ (unweathered), $W_{2}$ (slightly weathered), $W_{3}$ (moderately weathered), and $W_{4}$ (highly weathered) based on the ISRM descriptions.
The quantitative classification weathering states to rock samples is subjective, hence no common ground is established among the professionals according to Pinho, Rodrigues-Carvalho, Gomes, \& Duarte (2006) most importantly for highly weathered specimens. In this study, Igbeti marble samples with similar physical characteristics (colour, friability i.e. rock to soil ratio and texture) were grouped in the same grade. The classification of the Igbeti marble samples into different weathering grade is as presented in Figure 1.
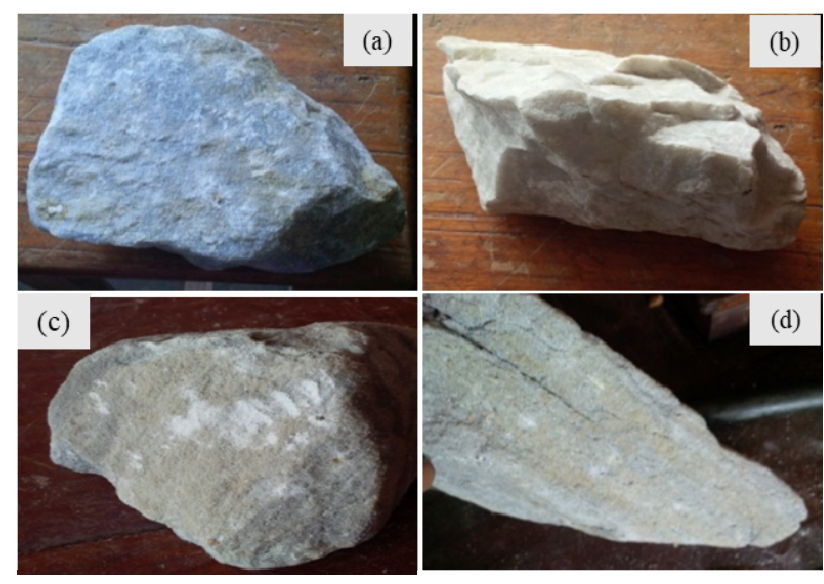

Figure 1. Description of Igbeti marble: (a) $W_{1}$ (colour: whitish grey; texture: coarse grained); (b) $W_{2}$ (colour: whitish; texture: fine to medium grained); (c) $W_{3}$ (colour: dark grey with some discolouration; texture: coarse grained); (d) $W_{4}$ (colour: greyish with evident of discolouration; texture: very coarse grained)

\subsection{Determination of mineralogical and chemical compositions}

The mineral content of the rocks was described in detail by means of thin section analysis using a petrographic microscope equipped with modal analysis device, e.g., point counter from a grid over the thin section. Photomicrographs of the samples were also taken to show features of geological interest.

The determination of major oxides and components of the samples was achieved by the X-ray fluorescence (XRF) spectrometer and the procedure adopted for the determination of components was that described by Jenkins and Snyder (1976).

\subsection{Determination of physical properties of selected rock samples}

The index properties (dry and bulk densities, water content, water absorption, porosity, and specific gravity) were determined in accordance with the standards suggested by (Brown, 1981). The specific gravity was determined using the pycnometer technique as suggested by ASTM D 854-00.

\subsection{Determination of mechanical properties of selected rock samples}

Cubical and irregular samples were used for the strength characterization in accordance with the suggested standards by (ISRM, 1985; ASTM, 2000). Uniaxial compressive strength test was characterized by loading a 
block (cubical) sample instead of the standard cylindrical sample while maintaining the length to thickness ratio of 2.5:1 under dry conditions axially until the specimen fails. The uniaxial compressive strength results were also corrected according to a standard size specimen with a diameter of 48 or $54 \mathrm{~mm}$ and a length to diameter ratio between 2 and 3 using the Turk and Dearman (1986) correction, as illustrated in the Equation (1):

$$
\frac{\delta_{50}}{U C S}=\frac{0.18 D}{\left(1.754+0.535\left(\frac{D}{L}\right)\right)},
$$

where:

$\delta_{50}$ - the uniaxial compressive strength of a $50 \mathrm{~mm}$ diameter rock;

$U C S$ - the uniaxial compressive strength of a rock specimen having a different diameter;

$D$ - the diameter of the specimen;

$L$ - the length of the specimen.

The point load strength test was conducted using the irregular sample based on Heidari, Khanlari, Torabi-Kaveh, \& Kargarian (2012) procedure. Point load strength results were corrected according to a standard size specimen with a diameter of $50 \mathrm{~mm}$ using the Hudson \& Harrison (1997) correction, as illustrated in the following Equation (2) and (3):

$$
I_{(50)}=\frac{F P}{D_{e}^{2}}
$$

where:

$$
\begin{aligned}
& F-\text { the correction factor; } \\
& P \text { - the failure load, } \mathrm{kN} ; \\
& D_{e} \text { - the equivalent core diameter, } \mathrm{mm} \text {. }
\end{aligned}
$$

$F=\left(\frac{D}{50}\right)^{\frac{9}{20}}$.

The tensile strength of the rock samples was estimated based on the relationship suggested by Brook (1993) and Brown (1981) which shows the general relationship between the point load strength $\left(I_{(50)}\right)$ and the tensile strength $\left(T_{o}\right)$ as expressed in Equation (4):

$$
T_{o}=1.51 I s_{(50)} \text {. }
$$

The slake durability index of the unweathered and the different weathered grades of Igbeti marble samples was also determined in accordance with the standard procedure as specified by the Brown (1981). Two solutions (slightly acidic rainwater and saturated $\mathrm{MgSO}_{4}$ salt) were used in this test. Selected representative marble samples of different weathering grade consisting of 10 lump each of $40-60 \mathrm{~g}$ providing a total sample weight ranging from 450 to $550 \mathrm{~g}$, roughly spherical in shape with corners rounded during preparation were prepared. Slightly acidic rainwater of $\mathrm{pH}$ of 5.68 and saturated $\mathrm{MgSO}_{4}$ salt solution was employed as the slaking fluids and the slake durability index was calculated after the second cycle. The rainwater of $\mathrm{pH}$ of 5.68 (slightly acidic) used was to monitor the effects of acid rain on the rock types while the saturated $\mathrm{MgSO}_{4}$ salt solution was to monitor the effects of salt crystallization.

\section{RESULTS AND DISCUSSION}

\subsection{Influence of weathering on mineral constituents of Igbeti marble samples}

Photomicrographs of the different weathering grades of Igbeti marble under polarized light are shown in Figure 2. Based on Figure 2, there existed some noticeable mineralogical changes that occur in the rock fabrics because of the increase in weathering. The proportion of the dominant constituents which are calcite and dolomite and other silicate and non-silicate minerals was found to relate directly to the degree of weathering.

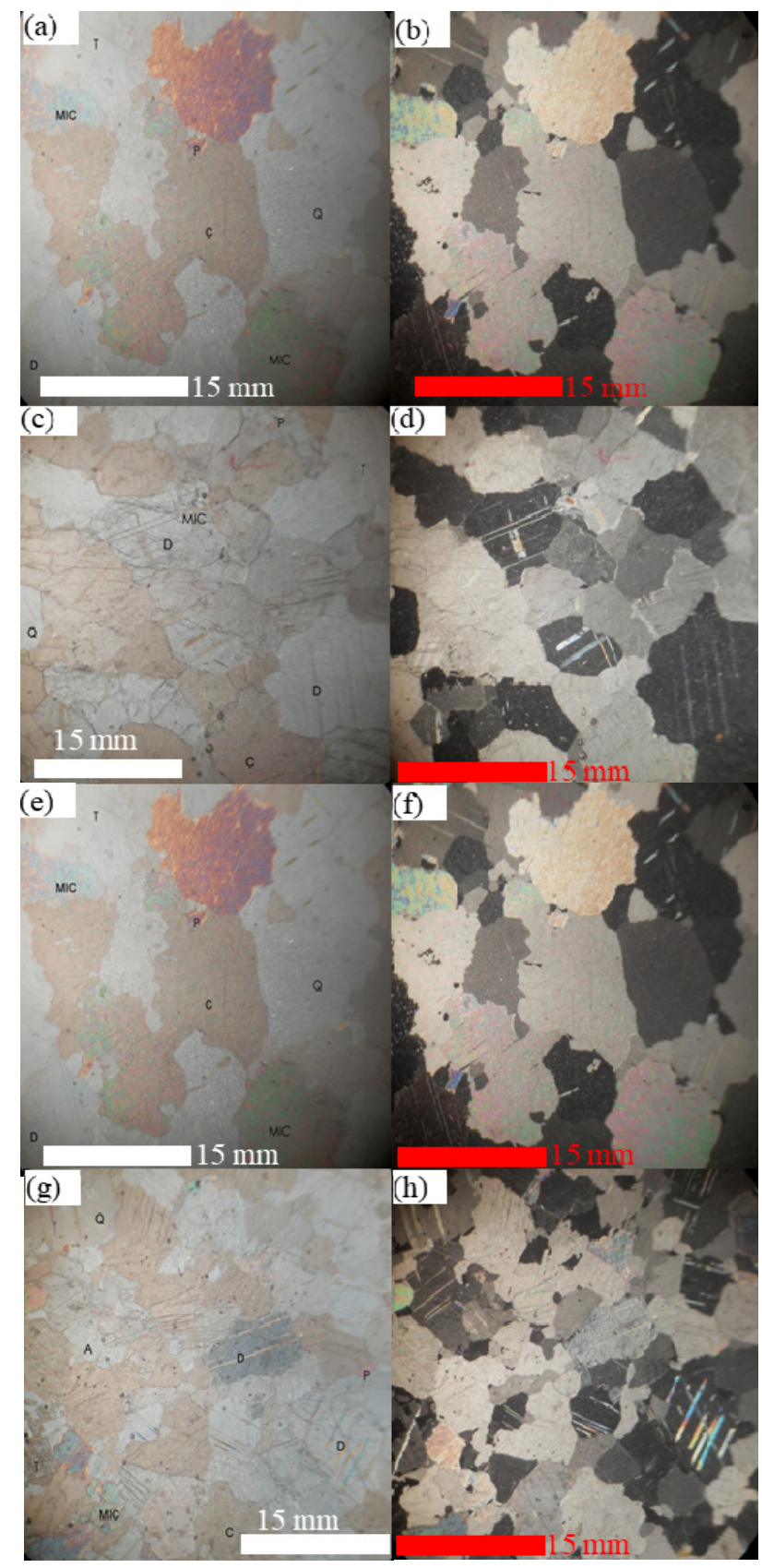

Figure 2. Photomicrographs of Igbeti marble under: (a) $W_{1}$ cross-polarized light; (b) W1 plane polarized light; (c) $W_{2}$ cross-polarized light; (d) $W_{2}$ plane polarized light; (e) $W_{3}$ cross-polarized light; $(f) W_{3}$ plane polarized light; (g) W4 cross-polarized light; (h) $W_{4}$ cross-polarized light; C-calcite; D-dolomite; MIC-muscovite (mica); $Q$-quartz; $P$-pyrite 
The calcite content, for example, decreases from $80.1 \%$ in $W_{1}$ to $79.8 \%$ in weathering grade $W_{2}$ and from $76.4 \%$ in $W_{3}$ to $73.2 \%$ in $W_{4}$. This showed the increase in weathering and weatherability from $W_{1}$ down to $W_{4}$ with the unweathered $\left(W_{1}\right)$ sample having more calcite content than the rest of the samples as shown in Figure 3. Similar trends were seen in dolomite, silicate and non-silicate minerals.

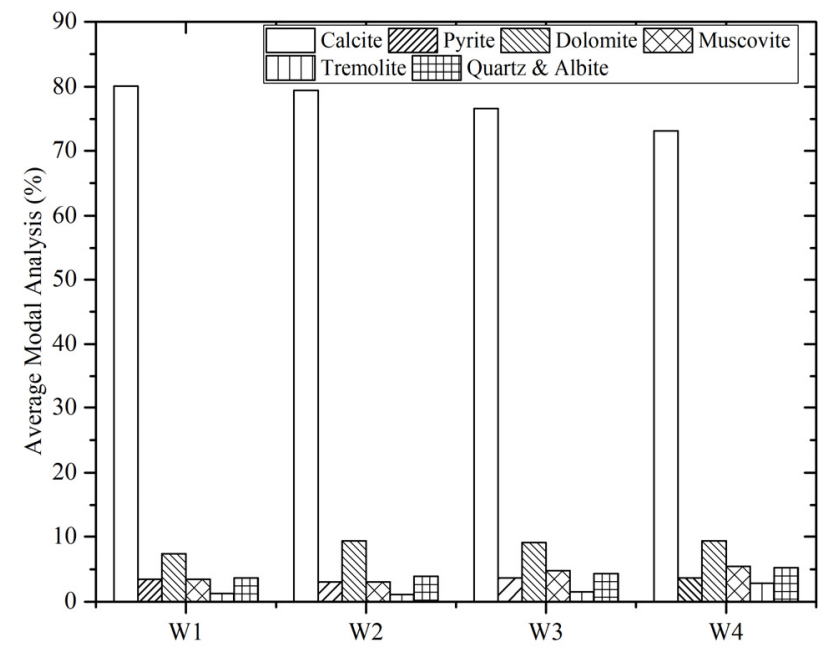

Figure 3. Average modal analysis of the major mineral constituents of the different weathering grades of Igbeti marble

The tremolite (a silicate mineral) increases as the weathering increase while quartz and albite (non-silicate) which is known to be impurities also increase as the weathering increase. The tremolite content is known to relate to the reaction of calcite with sand and clay contents in marble samples. The distribution of the different textural and mineral constituents in each of the weathering grade is shown in Figure 3.

\subsection{Geochemical analysis}

The geochemical analysis of the major elements/oxide for Igbeti marble samples are shown in Table 1. The concentration of four major oxide groups has been used to classify marble samples of different weathering profiles viz. calcium oxide $(\mathrm{CaO})$, silica oxide $\left(\mathrm{SiO}_{2}\right)$, iron oxide $\left(\mathrm{Fe}_{2} \mathrm{O}_{3}\right)$, and potassium (alkali) oxide $\left(\mathrm{K}_{2} \mathrm{O}\right)$.

Table 1. Major element analyses of the Igbeti marble with different weathering grades

\begin{tabular}{ccccc}
\hline $\begin{array}{c}\text { Oxides/ } \\
\text { elements }\end{array}$ & $W_{1}, \%$ & $W_{2}, \%$ & $W_{3}, \%$ & $W_{4}, \%$ \\
\hline $\mathrm{K}_{2} \mathrm{O}$ & $0.08 \pm 100$ & $0.04 \pm 100$ & $0.06 \pm 100$ & $0.05 \pm 100$ \\
$\mathrm{CaO}$ & $45.02 \pm 0.6$ & $43.62 \pm 0.5$ & $44.52 \pm 0.5$ & $39.60 \pm 0.6$ \\
$\mathrm{SiO}_{2}$ & $8.38 \pm 100$ & $8.16 \pm 100$ & $8.87 \pm 100$ & $10.25 \pm 100$ \\
$\mathrm{Fe}_{2} \mathrm{O}_{3}$ & $2.55 \pm 100$ & $3.58 \pm 100$ & $3.52 \pm 100$ & $4.18 \pm 100$ \\
$\mathrm{~V}_{2} \mathrm{O}_{5}$ & $0.31 \pm 100$ & $0.52 \pm 100$ & $0.29 \pm 100$ & $0.24 \pm 100$ \\
\hline
\end{tabular}

The quantitative identification of these four major oxides is important in the characterization of the quality of the samples. The $\mathrm{SiO}_{2}$ concentration which reflects the duration and intensity of weathering and destruction of other minerals during transportation shows an increasing trend as the weathering increases. High $\mathrm{SiO}_{2}$ concentration of about $10.25 \%$ observed in the $\left(W_{4}\right)$ sample may indicate a fluid inclusion which could be evidence for deep weathering of this sample. The high silica content observed could also be adduced probably to the incorporation of highly siliceous shells, the continental influx of silica as well as precipitation of $\mathrm{SiO}_{2}$ from solution.

$\mathrm{CaO}$ is the principal major oxide of most carbonate rocks especially marble, and its concentration in this rock type can be an indication of chemical weathering. The $\mathrm{CaO}$ concentration, unlike $\mathrm{SiO}_{2}$, decreases insignificantly as the weathering increase with the concentration of as high as $45.02 \%$ in the unweathered sample and a reduced concentration of $39.60 \%$ in the highly weathered sample.

$\mathrm{Fe}_{2} \mathrm{O}_{3}$ occurs as an impurity in the marble and the higher the value, the more deteriorated or weathered the marble samples are. As observed in this study, the concentration increases with increasing degree of weathering with highly weathered $W_{4}$ sample having a concentration of $4.18 \%$ compared to $2.55 \%$ in unweathered $W_{1}$ sample.

Finally, $\mathrm{K}_{2} \mathrm{O}$ concentration value for the unweathered $\left(W_{1}\right)$ sample is higher than the weathered samples i.e. decrease with increasing weathering. The percentage value by weight of the $W_{1}$ sample was $0.08 \%$ while that of $W_{2}, W_{3}$, and $W_{4}$ samples were $0.04 \%, 0.06 \%$, and $0.05 \%$ respectively. This indicated that $\mathrm{K}_{2} \mathrm{O}$ is rapidly leached and removed in the later stage of chemical weathering.

\subsection{Physical properties of rock samples}

The summary of statistics for the physical properties of the Igbeti marble in different weathering grades is shown in Table 2.

Table 2. Summary of statistics for the physical properties of the Igbeti marble in different weathering grades

\begin{tabular}{|c|c|c|c|c|c|}
\hline \multirow{2}{*}{$\begin{array}{c}\text { Test } \\
\text { method }\end{array}$} & \multirow{2}{*}{$\begin{array}{c}\text { Specimen } \\
\text { breakdown }\end{array}$} & \multicolumn{4}{|c|}{ ISRM weathering state } \\
\hline & & $W_{1}$ & $W_{2}$ & $W_{3}$ & $W_{4}$ \\
\hline \multirow{2}{*}{$\rho_{b}, \mathrm{~g} / \mathrm{cm}^{3}$} & $\mathrm{NS}^{*}$ & 10 & 10 & 10 & 10 \\
\hline & Average & 2.82 & 2.77 & 2.69 & 2.23 \\
\hline \multirow{2}{*}{$\rho_{d}, \mathrm{~g} / \mathrm{cm}^{3}$} & NS & 10 & 10 & 10 & 10 \\
\hline & Average & 2.74 & 2.68 & 2.61 & 2.13 \\
\hline \multirow{2}{*}{$\gamma, \mathrm{kN} / \mathrm{m}^{3}$} & NS & 10 & 10 & 10 & 10 \\
\hline & Average & 26.92 & 26.28 & 25.59 & 20.87 \\
\hline \multirow{2}{*}{$G_{\gamma}$} & NS & 5 & 5 & 5 & 5 \\
\hline & Average & 2.76 & 2.70 & 2.59 & 2.32 \\
\hline \multirow{2}{*}{$W_{C}, \%$} & NS & 3 & 3 & 3 & 3 \\
\hline & Average & 0.055 & 0.072 & 0.081 & 0.24 \\
\hline \multirow{2}{*}{$W_{a}, \%$} & NS & 3 & 3 & 3 & 3 \\
\hline & Average & 0.31 & 0.34 & 0.45 & 1.35 \\
\hline \multirow{2}{*}{$n, \%$} & NS & 3 & 3 & 3 & 3 \\
\hline & Average & 0.89 & 0.95 & 1.22 & 3.00 \\
\hline
\end{tabular}

*NS - the number of samples tested

The clear trend of the effect of weathering on the physical properties of selected rock samples can be seen in Figure 4. Each physical property is normalized with the values of weathering grade $1\left(W_{1}\right)$. This is very important to see the clear trend of the effects of weathering on the investigated physical property. The porosity, water content and water absorption increase with an increase in weathering grade while the bulk density, dry density, unit weight and specific gravity decrease with increase in weathering grade. 


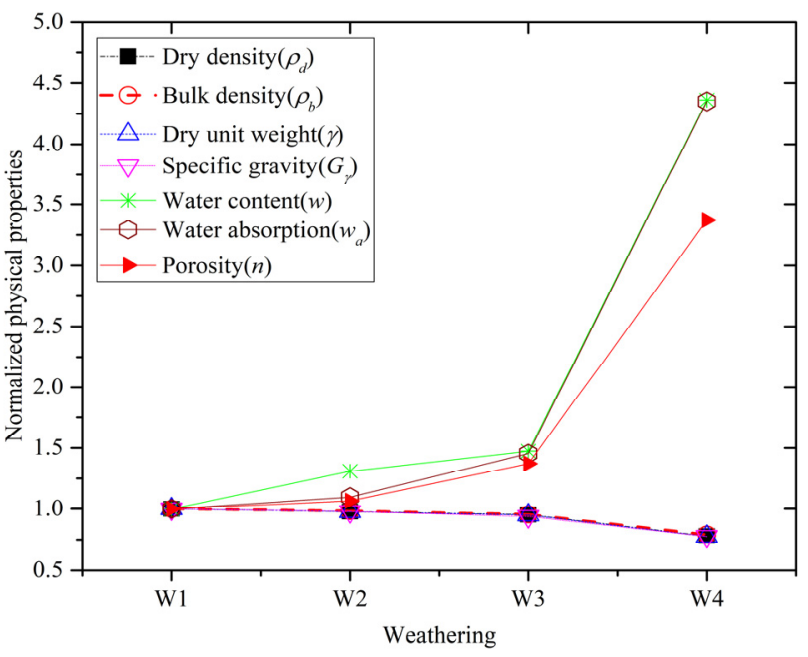

Figure 4. Normalized physical properties as a function of weathering states normalized with respect to $W_{1}$

This is an indication that the strength of the rock decreases as the degree of weathering increases. Figure 4 is very useful for the determination of weathering grades of similar rock samples by multiplying their respective physical properties investigated here with the respective corresponding dimensionless parameters shown in Figure 4.

Systematic trends are noted for bulk and dry densities as weathering indicators with an increasing degree of weathering. There are step reductions in these values from unweathered rock sample to the weathered sample as shown in Table 2. The observed trends in the results agree with that of Udagedara, Oguchi, \& Gunatilake (2017). Also, the values of bulk density and dry density agree with that of other metamorphic rocks. The relationship between the bulk and dry densities and weathering grades can be clearly seen in Figure 4 .

The ranges of unit weight and specific gravity decrease with increasing degree of weathering as shown in Figure 4 and Table 2. The decrease in specific gravity with respect to the weathering grades as being attributed to the increase in intergranular space and clay content of the rock as the weathering progresses (Arel \& Tugrul, 2001; Udagedara, Oguchi, \& Gunatilake 2017).

Absorption value defines the capacity of a rock to absorb water/moisture when immersed in water till saturation. There is an increase in the absorption value as the weathering increases in the Igbeti marble samples as shown in Figure 4 and Table 2. Igbeti marble samples have greater mean water content values across different weathering grades and the values increase with increasing degree of weathering.

Porosity test results are a direct indication of weathering state and weatherability in rocks. The more highly weathered the rock is, the more porous and less dense it is. The mean porosity values range from 0.89 to $3.00 \%$. It is seen that the porosity values increase with increasing weathering as it is also seen with water absorption and water content results as shown in Figure 4. The highest average value of $3.00 \%$ is seen in highly weathered $\left(W_{4}\right)$ samples. This high value could be attributed to the presence of wider openings in these samples. The low value obtained with marble samples could also be attributed to the fabric (microcracks and voids) of the samples which are believed to be closely packed most especially in the competent rock samples. The mean porosity value for unweathered $\left(W_{1}\right)$ sample is $0.89 \%$. Higher values are obtained with slightly weathered $\left(W_{2}\right)$ and moderately weathered $\left(W_{3}\right)$ samples with mean values of $0.95 \%$ and $1.22 \%$ respectively.

\subsection{Mechanical properties of the selected rock samples}

The summary of statistics for the mechanical properties of the Igbeti marble in different weathering grades is shown in Table 3 and the normalized values of the investigated mechanical properties are plotted against the weathering grades. The results show that almost all the mechanical properties of the studied rocks are affected by weathering processes.

Table 3. Summary of statistics for the mechanical properties of the Igbeti marble in different weathering grades

\begin{tabular}{cccccc}
\hline \multirow{2}{*}{$\begin{array}{c}\text { Test } \\
\text { method }\end{array}$} & $\begin{array}{c}\text { Specimen } \\
\text { breakdown }\end{array}$ & \multicolumn{4}{c}{ ISRM weathering state } \\
\cline { 3 - 6 }$I_{S(50)}, \mathrm{MPa}$ & $W_{1}$ & $W_{2}$ & $W_{3}$ & $W_{4}$ \\
& NS & 10 & 10 & 10 & 10 \\
& Average & 2.69 & 2.41 & 1.80 & 1.11 \\
\hline \multirow{2}{*}{$S R H$} & $\mathrm{NS}$ & 5 & 5 & 5 & 5 \\
& Average & 40.4 & 39.3 & 33.1 & 19.2 \\
\hline \multirow{2}{*}{$T_{o}, \mathrm{MPa}$} & $\mathrm{NS}$ & 10 & 10 & 10 & 10 \\
& Average & 4.04 & 3.62 & 2.69 & 1.58 \\
\hline \multirow{2}{*}{$U C S, \mathrm{MPa}$} & NS & 3 & 3 & 3 & 3 \\
& Average & 137.6 & 102.7 & 84.1 & $\mathrm{NA}^{* *}$ \\
\hline
\end{tabular}

*NS - the number of samples tested

${ }^{* *} \mathrm{NS}$ - no sample is available

Point load strength index and tensile strength are important indicators for rocks weathering, strength, and stability. In general, point load strength and tensile strength test result values decrease as the weathering increases as seen in Figure 5.

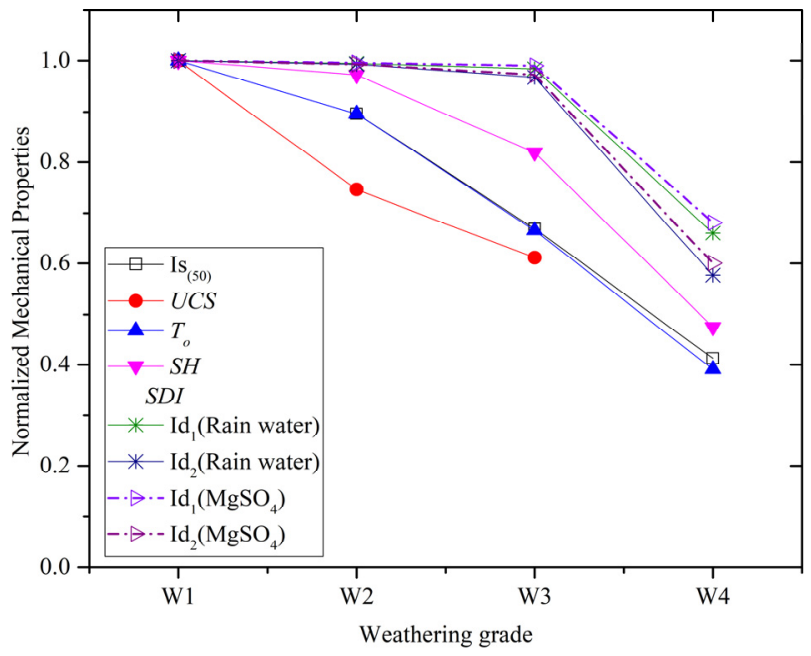

Figure 5. Normalized physical properties as a function of weathering states normalized with respect to $W_{1}$

As seen in Table 3, there is a wide range of point load strength and tensile strength test results for weathering states $W_{1}, W_{2}, W_{3}$, and $W_{4}$. The average point load strength test results for $W_{1}, W_{2}, W_{3}$, and $W_{4}$ are 2.69, 2.41, 1.80 and 1.11 MPa respectively. While the mean tensile strength 
test results for $W_{1}, W_{2}, W_{3}$, and $W_{4}$ are 4.04, 3.62, 2.69 and $1.58 \mathrm{MPa}$ respectively. The classification of strength index has been reduced from medium to moderate for the point load while it changes from high to moderate for tensile strength according to Bieniawski (1989) classification.

Schmidt rebound hardness numbers and compression results are an indication of the rock strength. The results are useful to assess the quality of various mineral constituents and bond strength that exist between mineral grains of the rock and to select rock suitable for various purposes. For Schmidt rebound hardness, there is a reduction in the values as weathering increases as seen in Figure 5 and Table 3.

The uniaxial compressive strength also shows a strong indication that the strength of rocks decreases with increase in weathering grades to the extent that the UCS disappears for the weathering grade $W_{4}$ as shown in Figure 5 and Table 3 . In general, UCS test result values decrease as the weathering increases as shown in Figure 5. The UCS has been reduced from high strength classification to extremely low strength classification according to Bieniawski (1989) classification.

Table 4 shows the slake durability index $(S D I)$ results of different weathering grades of marble respectively using slightly acidic rainwater of $\mathrm{pH}$ of 5.68 and saturated $\mathrm{MgSO}_{4}$ salt solution as the slaking fluid. The $S D I$ has been identified by the researchers (Gupta \& Rao, 2001; Dhakal, Yoneda, Kato, \& Kaneko, 2002) as one of the strength parameters that are sensitive to weathering. The $S D I$ values after the first and second cycles for unweathered $\left(W_{1}\right)$ sample using slightly acidic rainwater are 98.87 and $97.78 \%$ respectively. The SDI decreases as weathering in rocks increases and as such the values for slightly weathered, moderately weathered and highly weathered are lower compared with the unweathered sample as seen in Figure 5 for first and second cycles respectively.

Table 4. Summary of statistics for the slake durability index parameters of the marble in different weathering grades

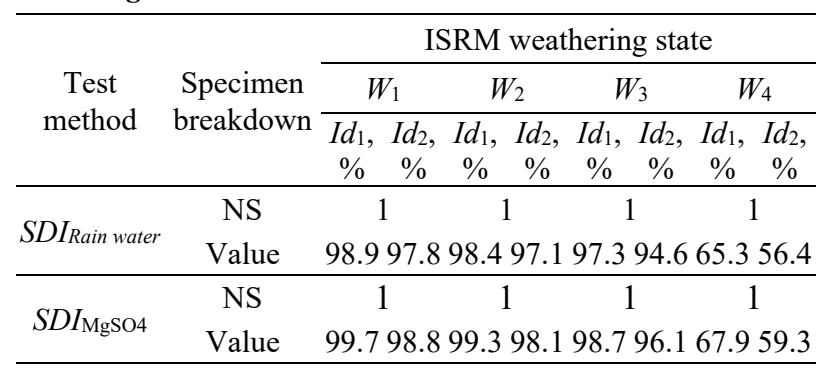

The SDI values after the first and second cycles for slightly weathered $\left(W_{2}\right)$ sample using slightly acidic rainwater are 98.36 and $97.11 \%$ respectively. Lastly, moderately weathered $\left(W_{3}\right)$ and highly weathered $\left(W_{4}\right)$ samples $S D I$ values after the first and second cycles using rainwater are 97.30 and $94.61 \%$; 65.31 and $56.40 \%$ respectively. The decrease in the $S D I$ with increasing degree of weathering could be attributed to the variation of the amounts of weak carbonic acid formed by the reaction of carbon dioxide with atmospheric moisture (rainwater) inside porous rocks, due to the difference of the porosity values for these rocks as shown previously.
The $S D I$ in the case of saturated $\mathrm{MgSO}_{4}$ salt solution as the slaking fluid is lower compared to that of slightly acidic rainwater of $\mathrm{pH}$ of 5.68. This could be attributed to the variation of the amounts of salt crystalline inside porous rocks, due to the difference of the porosity values for these rocks. It is shown in Figure 5 that the $S D I$ decreases with increasing degree of weathering and number of wetting/drying cycles.

The rate of percentage weight loss for first and second cycles respectively for samples of moderately weathered $\left(W_{3}\right)$ at 98.66 and $96.05 \%$ and highly weathered $\left(W_{4}\right)$ at 67.90 and $59.28 \%$ are greater than that of unweathered $\left(W_{1}\right)$ at 99.65 and $98.75 \%$ and slightly weathered $\left(W_{2}\right)$ at 99.27 and $98.08 \%$. This could be attributed to the higher porosity values of type $W_{3}$ and $W_{4}$, which help to decrease the resistance of these rock samples to deterioration by the action of a saturated solution of $\mathrm{MgSO}_{4}$.

\section{CONCLUSIONS}

In this study, the physico-mechanical, mineralogical and geochemical properties variations in Igbeti marble, South-Western Nigeria under the influence of weathering are investigated. From the results of the laboratory testing and analyses carried out on the selected rock samples, the following conclusions are drawn:

1. The physico-mechanical properties investigated varies considerably with increasing degree of weathering. While the bulk density, dry density, dry unit weight, specific gravity, uniaxial compressive strength, point load strength, tensile strength, and Schmidt hardness decrease with weathering, others such as water/moisture content, water absorption and porosity increases with increasing degree of weathering.

2. Noticeable mineralogical changes occur in the rock fabrics because of the increasing degree of weathering on the samples. The proportion of the dominant constituents which are calcite and dolomite and other silicate and non-silicate minerals was found to relate directly to the degree of weathering.

3. Major oxides distribution in conjunction with other determinants has been successfully used to show the effects of chemical weathering on the rock samples. The quantitative identification of the four major oxides is important in the characterization of the quality of the samples.

\section{ACKNOWLEDGMENTS}

The authors appreciate the custodians of rock mechanics laboratory at the Federal University of Technology Akure, Nigeria, geology laboratory at the University of Ibadan, Oyo State, Nigeria and Centre for Energy Research and Development at Obafemi Awolowo University Ile-Ife, Osun State, Nigeria for making the laboratories available for the experiments.

\section{REFERENCES}

Arel, E., \& Tugrul, A. (2001). Weathering and its relation to geomechanical properties of Cavusbasi granitic rocks in northwestern Turkey. Bulletin of Engineering Geology and the Environment, 60(2), 123-133.

https://doi.org/10.1007/s100640000091 
ASTM D5873-00. (2000). Standard test method for determination of rock hardness by rebound hammer method. West Conshohocken, United States: American Society for Testing and Materials International.

ASTM D854-00. (2000). Standard test methods for specific gravity of soil solids by water pycnometer. West Conshohocken, United States: American Society for Testing and Materials International.

Bieniawski, Z.T. (1989). Engineering rock mass classifications, a complete manual for engineers and geologists in mining, civil and petroleum engineering. New York, United States: John Wiley and Sons.

Brook, N. (1993). The measurement and estimation of basic rock strength. Rock Testing and Site Characterization, Principle Practice, and Projects, 41-46. https://doi.org/10.1016/b978-0-08-042066-0.50009-4

Brown, E.T. (1981). Rock characterization, testing \& monitoring: ISRM suggested methods. Rock characterization testing and monitoring. Oxford, United Kingdom: Pergamon Press.

Dhakal, G., Yoneda, T., Kato, M., \& Kaneko, K. (2002). Slake durability and mineralogical properties of some pyroclastic and sedimentary rocks. Engineering Geology, 65(1), 1-45. https://doi.org/10.1016/S0013-7952(01)00101-6

Gupta, A.S., \& Rao, S.K. (2001). Weathering indices and their applicability for crystalline rocks. Bulletin of Engineering Geology and the Environment, 60(3), 201-221. https://doi.org/10.1007/s100640100113

Heidari, M., Khanlari, G., Torabi-Kaveh, M., \& Kargarian, S. (2012). Predicting the uniaxial compressive and tensile strengths of gypsum rock by point load testing. Rock Mechanics Rock Engineering, 45(2), 265-273. https://doi.org/10.1007/s00603-011-0196-8

Hudson, J.A., \& Harrison, J.P. (1997). Engineering rock mechanics: an introduction to the principles. Oxford, United Kingdom: Elsevier.

Irfan, T.Y. (1996). Mineralogy, fabric properties and classification of weathered granites in Hong Kong. Quarterly Journal of Engineering Geology, 29(1), 5-35.

https://doi.org/10.1144/GSL.QJEGH.1996.029.P1.02
ISRM. (1985). Suggested method for determining point-load strength. International Journal of Rock Mechanics and Mining Science and Geomechanics, 22(2), 51-60. https://doi.org/10.1016/0148-9062(85)92327-7

Jenkins, R., \& Synder, R.L. (1976). Introduction to X-Ray powder diffractometry. New York, United States: Willey. https://doi.org/10.1002/9781118520994

Musbau, A.F. (2014). Geology and mineral resources of Oyo State, south western Nigeria. Journal of Scientific Research and Reports, 3(21), 2718-2731. https://doi.org/10.9734/JSRR/2014/11569

Pinho, A., Rodrigues-Carvalho, J., Gomes, C., \& Duarte, I. (2006). Overview of the evaluation of the state of weathering by visual inspection. Proceedings of the $10^{\text {th }}$ IAEG International Congress, Geological Society of London.

Rigopoulos, I., Tsikouras, B., Pomonis, P., \& Hatzipanagiotou, K. (2010). The influence of alteration on the engineering properties of dolerite: the examples from the Pindos and Vourinos Ophiolites (Northern Greece). International Journal of Rock Mechanics \& Mining Science, (47), 69-80. https://doi.org/10.1016/j.ijrmms.2009.04.003

Serra, R. (2006). Dictionary of geology. New Delhi, India: Academic Publishers.

Thuro, K., \& Scholz, M. (2004). Deep weathering and alteration in granites - a product of coupled processes. Elsevier Geo-Engineering Book Series, (2), 785-790. https://doi.org/10.1016/S1571-9960(04)80134-4

Turk, N., \& Dearman, W.R. (1986). A new procedure for determination of point load strength in site investigation. Geological Society, London, Engineering Geology Special Publications, (2), 405-411. https://doi.org/10.1144/GSL.1986.002.01.67

Udagedara, D.T., Oguchi, C.T., \& Gunatilake, J.K. (2017). Evaluation of geomechanical and geochemical properties in weathered metamorphic rocks in tropical environment: a case study from Samanalawewa hydropower project, Sri Lanka. Geosciences Journal, 21(3), 441-452. https://doi.org/10.1007/s12303-016-0060-7

\section{ЗМІНА ФІЗИКО-МЕХАНІЧНИХ, МІНЕРАЛОГІЧНИХ І ГЕОХІМІЧНИХ ВЛАСТИВОСТЕЙ МАРМУРУ ПІД ВПЛИВОМ ВИВІТРЮВАННЯ}

\section{Н.О. Огунсола, А.І. Лавал, М.А. Саліу}

Мета. Вивчення змін фізико-механічних, мінералогічних і геохімічних властивостей мармуру родовища Ігбеті (південно-Західна Нігерія) під впливом вивітрювання.

Методика. Було відібрано 20 репрезентативних зразків на різних глибинах залягання породи (максимум 30 м) у районі родовища. У відповідності з класифікаційними індексами вивітрювання зразки були розділені на групи: невивітрені, слабо вивітрені, помірно вивітрені, сильно вивітрені. Було виготовлено тонкі стрічки для вивчення текстурних і мінералогічних характеристик. Аналіз хімічного складу зразків проводився із використанням рентгенофлуоресцентної спектрометрії (РФС). Також була проведена оцінка фізико-механічних властивостей зразків.

Результати. Результати досліджень показали, що значні мінеральні та хімічні зміни у товщі породи пов'язані з наростанням впливу вивітрювання. Встановлено за даними лабораторних досліджень, що об'ємна щільність, суха щільність, суха та питома вага, збільшуються з підвищенням ступеня вивітрювання, проте зміст води/вологи, водопоглинання, пористість, міцність на одноосьове стиснення, міцність при точковому навантаженні, міцність на розтяг та твердість за Шмідтом зменшуються. Встановлено зв'язок кількості домінуючих компонентів (кальцит і доломит) та інших силікатних і несилікатних мінералів зі ступенем вивітрювання.

Наукова новизна. Для умов родовища Ігбеті виявлено характер та особливості впливу ступеня вивітрювання на зміну фізико-механічних і геохімічних властивостей мармурових порід метаморфічного типу, у той час як попередні дослідження присвячені осадовим та магматичним породам.

Практична значимість. Результати досліджень необхідно враховувати в архітектурному та інженерному використанні у різних кліматичних зонах. Поняття впливу вивітрювання на властивості гірських порід $є$ важливим критерієм для визначення глибини розробки, конструкції похилого схилу, методу, простоти видобутку та напрямів використання мармуру, що дозволить зменшити вартість і поліпшити роботи з розвідки й видобування.

Ключові слова: мармур, вивітрювання, фізико-механічні властивості, мінералогічні властивості, РФС, геохімічний аналіз 


\section{ИЗМЕНЕНИЕ ФИЗИКО-МЕХАНИЧЕСКИХ, МИНЕРАЛОГИЧЕСКИХ И ГЕОХИМИЧЕСКИХ СВОЙСТВ МРАМОРА ПОД ВЛИЯНИЕМ ВЫВЕТРИВАНИЯ}

\section{Н.О. Огунсола, А.И. Лавал, М.А. Салиу}

Цель. Изучение изменения физико-механических, минералогических и геохимических свойств мрамора месторождения Игбети (Юго-Западная Нигерия) под влиянием выветривания.

Методика. Было отобрано 20 репрезентативных образцов на различных глубинах залегания породы (максимум - 30 м) в районе месторождения. В соответствии с классификационными индексами выветривания образцы были разделены на группы: невыветренные, слабо выветренные, умеренно выветренные, сильно выветренные. Были изготовлены тонкие срезы для изучения текстурных и минералогических характеристик образцов. Анализ химического состава образцов проводился с использованием рентгенофлуоресцентной спектрометрии (РФС). Была также проведена оценка физико-механических свойств образцов.

Результаты. Результаты исследований показали, что значительные минералогические и химические изменения в толще породы связаны с нарастающим влиянием выветривания. Установлено по данным лабораторных исследований, что объемная плотность, сухая плотность, сухой вес и удельный вес увеличиваются с увеличением степени выветривания, а содержание воды/влаги, водопоглощение, пористость, прочность на одноосное сжатие, прочность при точечной нагрузке, прочность на растяжение и твердость по Шмидту уменьшаются. Установлена связь количества доминирующих компонентов (кальцит и доломит) и других силикатных и несиликатных минералов со степенью выветривания.

Научная новизна. Для условий месторождения Игбети выявлен характер и особенности влияния степени выветривания на изменение физико-механических и геохимических свойств мраморных пород метаморфического типа, в то время как предыдущие исследования посвящены осадочным и магматическим типам пород.

Практическая значимость. Результаты исследований необходимо учитывать в архитектурном и инженерном использовании в разных климатических зонах. Понимание влияния выветривания на свойства горных пород является важным критерием для определения глубины разработки, конструкции наклонного склона, метода, простоты добычи и направлений использования мрамора, что в итоге позволит снизить стоимость и облегчить работу по разведке и выемке.

Ключевые слова: мрамор, выветривание, физико-механические свойства, минералогические свойства, РФС, геохимический анализ

\section{ARTICLE INFO}

Received: 7 October 2018

Accepted: 14 February 2019

Available online: 26 February 2019

\section{ABOUT AUTHORS}

Nafiu Olanrewaju Ogunsola, Former Master Student of the Department of Mining Engineering, Federal University of Technology Akure, Ilesha-Akure Expressway, P.M.B. 704, Akure, Ondo State, Nigeria. E-mail: olanrewajuogunsola33@gmail.com

Abiodun Ismail Lawal, Doctor of Philosophy, Lecturer of the Department of Mining Engineering, Federal University of Technology Akure, Ilesha-Akure Expressway, P.M.B. 704, Akure, Ondo State, Nigeria. E-mail: ailawal@futa.edu.ng

Muyideen Alade Saliu, Doctor of Philosophy, Associate Professor of the Department of Mining Engineering, Federal University of Technology Akure, Ilesha-Akure Expressway, P.M.B. 704, Akure, Ondo State, Nigeria. E-mail: masaliu@,futa.edu.ng 